\title{
STRATEGI BERSAING BIRO PERJALANAN WISATA ALINDO DEWATA TOURS BALI
}

\author{
Nelsye Natalina Lintong \\ Email:nel_sye@hotmail.com
}

\begin{abstract}
Alindo Dewata Tours Bali as an inbound tours company deals with the competitors by applying competitive strategy. Nevertheless the competitive strategy applied is not maximum yet. It is apparently seen at the average growth of tourists number handled since 2004-2013 by the company only 5,97\%. Therefore, this study has the objective to know what internal external factors that give influences and competitive strategy to be applied in the company. This research using analysis tools of Internal Factor Evaluation (IFE) matrix, External Factor Evaluation (EFE) matrix for general strategy, Internal External (IE) matrix, Strength Weakness Opportunity Threat (SWOT) matrix for alternative strategy and Quantitative Strategic Planning Matrix (QSPM) for priority strategy. The result of IFE matrix indicates bundle pricing policy as the prime strength and the application of the management information system not maximum as the prime weakness. EFE matrix indicates quality strategy contributes the service as prime opportunity and the dependency on the foreign travel agencies as prime threat. Based on IE matrix, the company's position is at five (V) level for resistance and endurance strategy. SWOT matrix indicates eight competitive strategic alternatives. Suggested first priority by QSPM is to develop market segment, both overseas and domestic market.
\end{abstract}

Key word: Competitive strategy, inbound tours, industrialorganization, resource-based view.

\section{Pendahuluan}

Bali merupakan destinasi wisata utama di Indonesia. Perkembangan pariwisata di Bali berkaitan erat dengan peranan seluruh komponen industri pariwisata, seperti akomodasi, biro perjalanan wisata yang tergabung dalam Association of Indonesian Tour and Travel Agencies, (ASITA) Bali, pramuwisata, transportasi, dan atraksi wisata. Setiap komponen industri pariwisata terlibat dalam mekanisme pengaturan kegiatan dan berintegrasi 


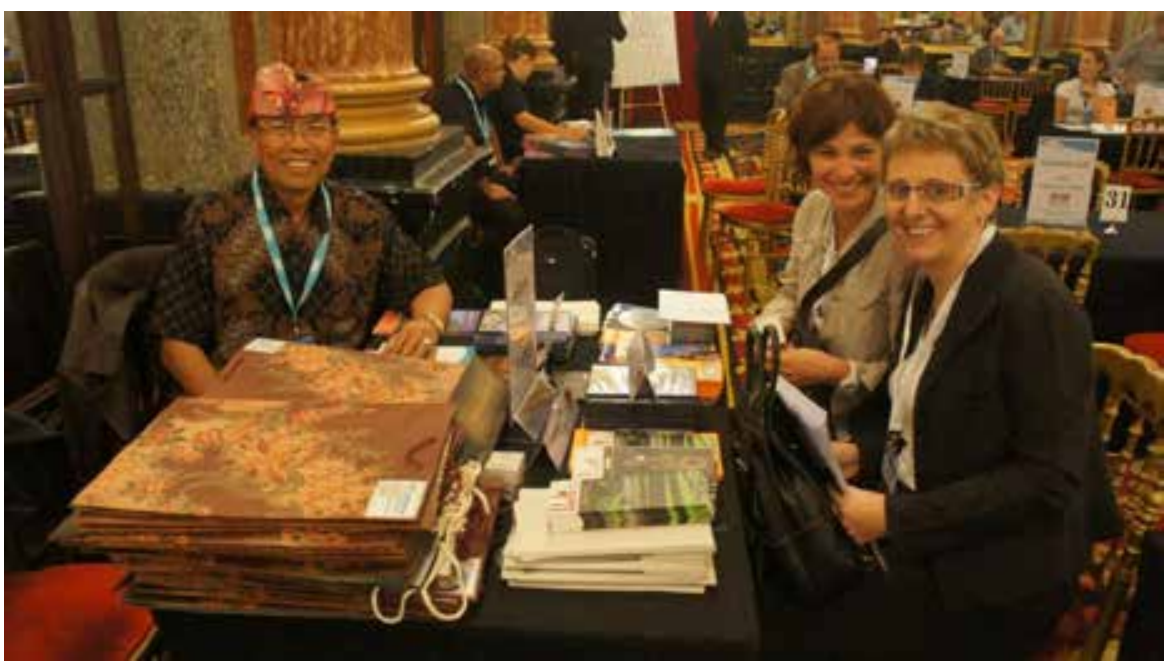

DOKUMEN PERUSAHAAN

Foto 1. Putu Djirna, perwakilan perusahaan Alindo, sewaktu mengikuti pasar wisata Top Resa di Perancis, tahun 2012

untuk memberikan pelayanan terbaik bagi wisatawan.

Biro perjalanan wisata (BPW) sebagai salah satu komponen industri pariwisata, menjadi penghubung antara pengguna dan penyedia jasa dengan mengatur atau merencanakan perjalanan wisatawan (Foster, 2000:78). Berdasarkan data ASITA Bali, keanggotaannya mencapai 375 BPW yang terdiri dari perusahaan inbound dan outbound. Banyaknya BPW memunculkan permasalahan persaingan, baik antara perusahaan lokal maupun cabang dari perusahaan di luar Bali dan luar negeri. Picard (2006:83-84) menyatakan bahwa, biro perjalanan wisata lokal yang berintegrasi dengan perusahaan luar, baik dalam negeri maupun luar negeri, memiliki kemampuan lebih, terkait dengan profesionalisme.

Persaingan tidak saja terjadi di antara BPW, namun keberadaan teknologi internet semakin melemahkan peranan biro perjalanan wisata. Berbagai informasi pariwisata yang sebelumnya hanya diperoleh dari biro perjalanan wisata, kini dilakukan dengan mudah melalui internet (Tsiotsu dan Ratten, 2010:538), sehingga wisatawan bisa mengatur rencana perjalanannya sendiri.

Alindo Dewata Tours merupakan salah satu BPW anggota ASITA yang bergerak dalam kegiatan inbound tourism. Inbound tourism menangani wisatawan yang masuk ke dalam negeri dan melakukan pemasaran di luar negeri (Vellas dan Becherel, 2008:16). Perusahaan mengantisipasi persaingan dengan melaksanakan strategi bersaing secara offline dan online. Upaya strategi bersaing offline di antaranya dengan menghadiri beberapa forum pariwisata nasional dan internasional (Lihat Foto 1). Strategi bersaing online dilakukan perusahaan melalui penyediaan beberapa website yang dimiliki (Lihat Foto 2). 


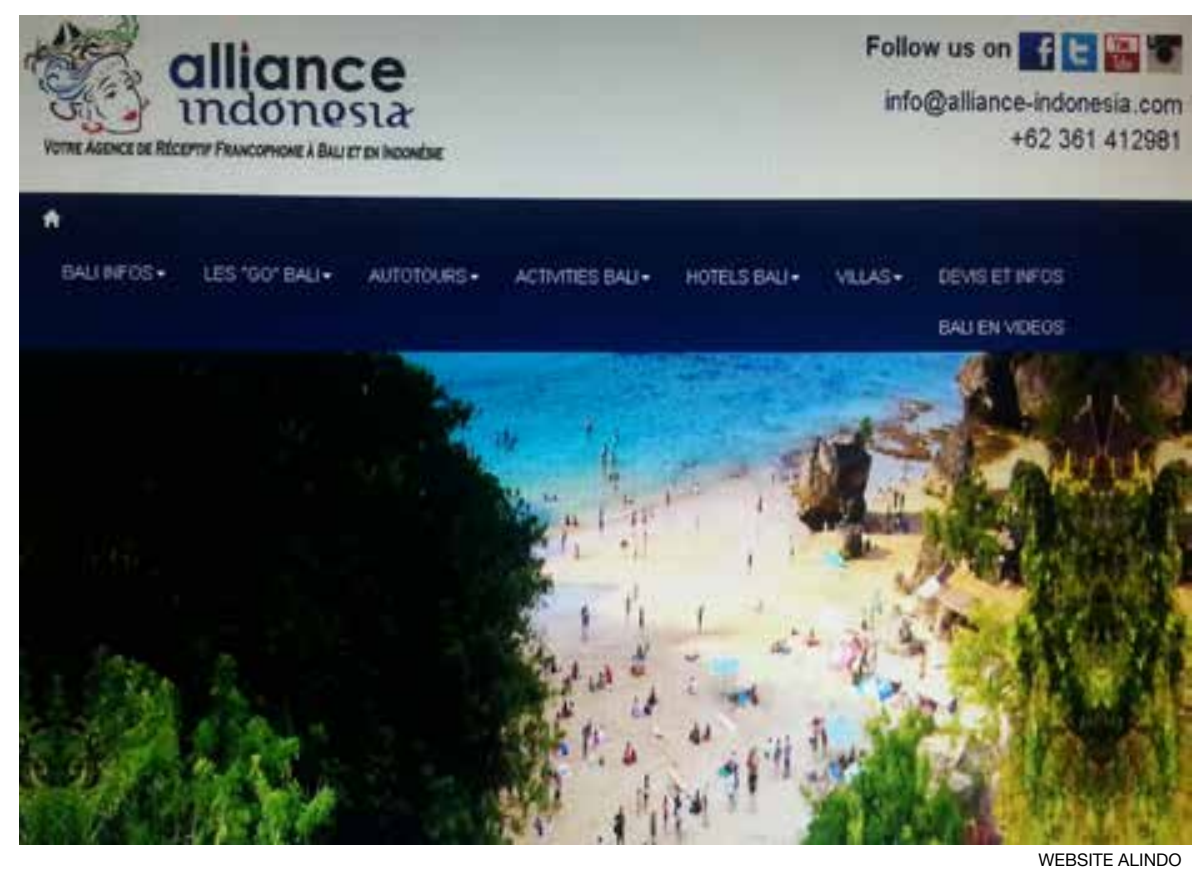

Foto 2. Website Perusahaan Alindo: www.alliance-indonesia.fr

Wisatawan asal negara Perancis paling banyak ditangani oleh perusahaan. Mengantisipasi besarnya potensi pasar Perancis, perusahaan melibatkan dua ekspatriat dari Perancis dalam kegiatan operasionalnya (Foto 3). Perusahaan juga memiliki lima personil, dua dari tim manajemen dan tiga karyawan berbahasa Perancis, sebagai upaya memberikan pelayanan maksimal kepada relasi bisnis dan wisatawan berbahasa Perancis. Berdasarkan data perusahaan dari tahun 2004-2013, tingkat pertumbuhan wisatawan yang ditangani hanya mencapai $5,97 \%$. Indikator ini menunjukkan masih rendahnya tingkat pertumbuhan jumlah wisatawan yang ditangani perusahaan. Adanya ketidaksesuaian antara upaya strategi bersaing yang telah dilakukan dengan jumlah wisatawan yang ditangani oleh perusahaan, menunjukkan pentingnya penelitian ini untuk dilakukan.

Berdasarkan latar belakang masalah yang sudah diuraikan, maka rumusan masalah yang diajukan dalam penelitian ini, yaitu faktorfaktor lingkungan internal dan eksternal serta strategi bersaing pada Biro Perjalanan Wisata Alindo Dewata Tours. Tujuan dari penelitian ini adalah untuk menganalisis faktor-faktor lingkungan internal dan eksternal, serta merumuskan strategi bersaing BPW Alindo Dewata Tours. Hasil penelitian ini diharapkan bisa menjadi bahan kajian penelitian selanjutnya, terutama terhadap permasalahan yang belum terungkap. 


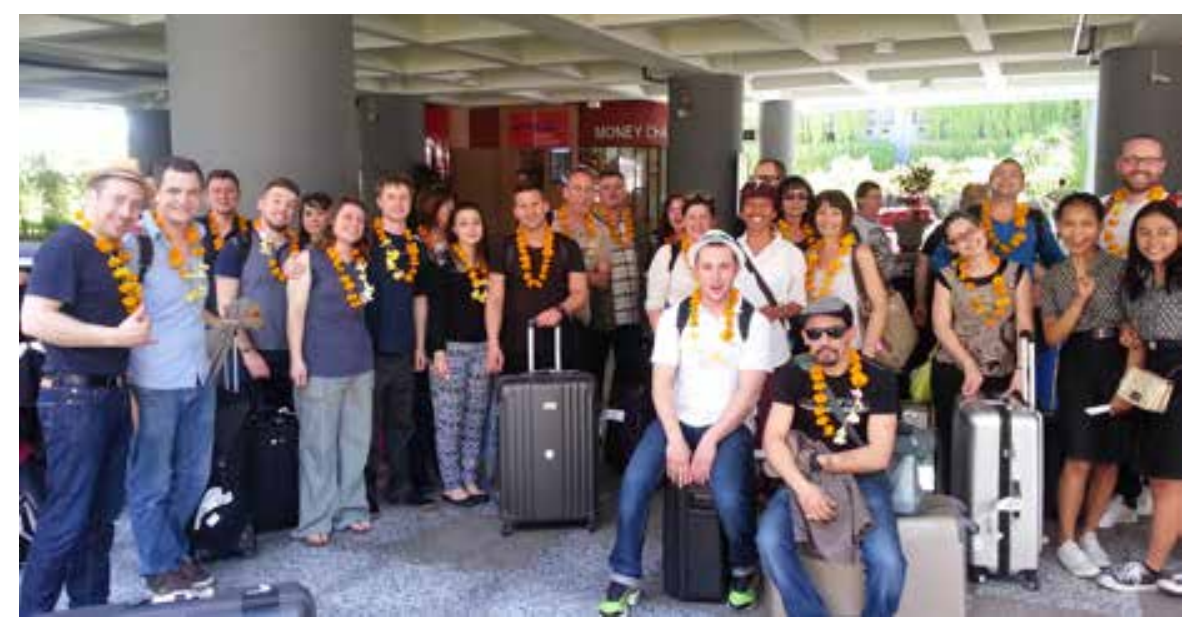

NELSYE NATALINA LINTONG

Foto 3. Group Perancis yang ditangani oleh Perusahaan Alindo pada April 2015.

\section{Teori dan Metode}

Teori yang digunakan dalam penelitian ini adalah teori Resource Based View (RBV), IO dan strategi bersaing. Teori RBV menurut Mahoney dan Pandian (1992:363) mencakup tiga perspektif, yaitu: penggabungan antara wawasan strategi tradisional terkait kompetensi unik dan heterogenitas kemampuan perusahaan, paradigma ekonomi organisasi dan bersifat komplementer terhadap penelitian organisasi industri. Teori RBV digunakan untuk menguraikan faktor internal yang dimiliki oleh perusahaan.

Church dan Ware (2000:7,10) mengemukakan teori IO atau organisasi industri merupakan pembelajaran tentang operasional dan performa terhadap persaingan pasar yang tidak sempurna dan perilaku perusahaanperusahaan yang berada dalam pasar-pasar tersebut. Teori IO digunakan untuk menguraikan faktor eksternal yang dihadapi perusahaan.

Teori strategi bersaing menurut Langabeerll dan Napiewocki (2000:100) adalah langkah-langkah terhadap jajaran lingkungan yang dihadapi organisasi dengan cara melakukan respon melalui strategi yang sesuai, sehingga akan mengurangi pengaruh eksternal dan menjadikan organisasi pada arah tujuan yang sebenarnya. Teori strategi bersaing sebagai pedoman perumusan strategi bersaing yang sebaiknya diterapkan oleh perusahaan.

Metode yang digunakan dalam penelitian ini adalah gabungan antara kualitatif dan kuantitatif. Setiap metode bisa digunakan untuk saling melengkapi dalam area penelitian yang sama, dikarenakan masing-masing memiliki kegunaan yang berbeda (Susan Stainback dalam Sugiyono, 2010:27). Metode kualitatif digunakan untuk mengidentifikasi faktorfaktor internal dan eksternal perusahaan. Selanjutnya faktor-faktor internal dan eksternal diproses melalui serangkaian formulasi, guna menemukan 
alternatif-alternatif strategi bersaing. Serangkaian proses formulasi tersebut merupakan metode kuantitatif. Penerapan metode kualitatif dan kuantitatif menghasilkan strategi bersaing yang tepat bagi BPW Alindo Dewata Tours.

Penelitian ini dilakukan pada BPW Alindo Dewata Tours yang terletak di Jalan Gunung Agung, Gang Indus No. 4, Denpasar, Bali, Indonesia. Pemilihan Biro Perjalanan Wisata Alindo Dewata Tours sebagai obyek penelitian dengan pertimbangan, bahwa terdapat permasalahan yang relevan dengan materi penulisan.

Jenis data pada penelitian ini menggabungkan data kualitatif dan kuantitatif, guna menguraikan faktor-faktor internal dan eksternal. Data kualitatif berupa uraian informasi, seperti produk-produk wisata, strategi bersaing yang dilakukan perusahaan, segmenting targeting positioning dan penerapan bauran pemasaran. Data kuantitatif berupa uraian jumlah kunjungan wisatawan ke Bali dan yang ditangani oleh perusahaan.

Sumber data primer dan sekunder menjadi acuan dalam proses penelitian ini. Data primer diperoleh secara langsung dari informan dan responden, untuk mengetahui strategi bersaing yang telah dan sedang dilakukan oleh perusahaan. Data sekunder diperoleh dari publisitas berbagai instansi terkait, seperti siaran pers Bank Indonesia dan Badan Pusat Statistik.

Penelitian ini menggunakan instrumen kuesioner untuk memperoleh data yang diperlukan. Serangkaian kuesioner diberikan kepada informan dan responden. Kuesioner kepada informan terkait penerapan strategi bersaing yang dilakukan oleh perusahaan. Kuesioner kepada responden berupa unsur-unsur bauran pemasaran.

Penentuan informan dilakukan berdasarkan atas kriteria atau pertimbangan tertentu (Wirartha 2006:241), yaitu orang yang paham mengenai kebijakan strategi bersaing yang diterapkan perusahaan. Penentuan informan dari perusahaan ditujukan kepada pihak manajemen (Infomran 1) dan karyawan senior (Informan 2). Informan dari luar perusahaan adalah Director BPW Incito di Makasar, Sulawesi Selatan dan Chief Operating Officer Panorama Tours di Jakarta. Kriteria responden ditentukan berdasarkan teknik sampel non-random secara kebetulan, dengan mengajukan pertanyaan pada orangorang yang dijumpai (Wardiyanta, 2006:23), dalam hal ini wisatawan yang sedang ditangani oleh Alindo. Penentuan responden dari wisatawan, yaitu wisatawan yang sedang berkunjung ke Bali dan ditangani oleh Alindo dalam periode penelitian.

Penelitian ini menggunakan beberapa teknik pengumpulan data, guna memperoleh data yang akurat dan obyektif, yaitu melalui observasi, wawancara dan dokumentasi. Observasi dilakukan dengan cara mengumpulkan data berdasarkan pengamatan secara langsung terhadap aktifitas dalam perusahaan terkait dengan pelaksanaan strategi bersaing. Wawancara mendalam dilakukan terhadap informan dari dalam perusahaan, luar perusahaan, 
sedangkan relasi bisnis di dalam dan luar negeri melalui fitur layanan pada telepon genggam, serta koresponden email. Dokumentasi merupakan pengumpulan data dari perusahaan dan berbagai instansi terkait, seperti badan pusat statistik, dinas pariwisata dan asosiasi penyelenggara jasa internet.

Data yang diperoleh dianalisis secara deskriptif analitis, artinya data terlebih dahulu diklasifikasi menurut kelompoknya kemudian dianalisis dengan menggunakan pendekatan penyusunan strategi bersaing sesuai dengan kerangka perumusan strategi dari David (2004:285). Langkahlangkah analisis data secara rinci disajikan pada bagian berikut.

\subsection{Analisis Lingkungan Perusahaan}

Data lingkungan perusahaan diperoleh dari informan dan responden. Selanjutnya, data diidentifikasi menggunakan SWOT menjadi dua kategori, yaitu lingkungan internal untuk data internal dan eksternal untuk data eksternal.

Lingkungan Internal Perusahaan. Data internal yang diperoleh dari dalam perusahaan diklasifikasikan ke dalam aspek manajemen, pemasaran, keuangan, produk/operasional, penelitian/pengembangan dan sistem informasi manajemen (SIM).

Lingkungan Eksternal Perusahaan. Data eksternal yang diperoleh dari luar lingkungan perusahaan, selanjutnya diklafisikasikan ke dalam aspek ekonomi, sosial budaya, demografi, lingkungan, politik, pemerintah, hukum, teknologi dan lingkungan persaingan.

\subsection{Strategi Bersaing}

Berdasarkan hasil analisis terhadap lingkungan internal dan eksternal, maka dapat dilakukan perumusan strategi bersaing melalui tiga tahap, yaitu strategi umum, alternatif dan prioritas.

Strategi umum dilakukan melalui matriks Internal Factor Evaluation (IFE) dan External Factor Evaluation (EFE).

Strategi Alternatif menggunakan dua matriks, yaitu Internal External (IE) dan Strength Weakness Opportunity Threat (SWOT).

Strategi prioritas dilakukan melalui analisis Quantitative Strategic Planning Matrix (QSPM), berdasarkan data dari strategi umum dan alternatif.

\section{Pembahasan}

\subsection{Analisis Lingkungan Internal Perusahaan}

Analisis lingkungan internal perusahaan berdasarkaan teori Resource Based View (RBV), mengutamakan pandangan internal yang menjadi dasar keputusan perusahaan. Hasil analisis terhadap lingkungan internal yang mencakup faktor kekuatan dan kelemahan perusahaan diidentifikasi 
menggunakan SWOT.

\section{Identifikasti SWOT terhadap faktor kekuatan}

Faktor-faktor yang menjadi kekuatan perusahaan, adalah: pembagian kerja jelas sesuai dengan struktur organisasi, rekrutmen sesuai tingkat pendidikan dan kemampuan, perusahaan mempekerjakan dua orang ekspatriat dari Perancis, paket wisata bervariasi sesuai kemampuan wisatawan, pemasaran dilakukan secara offline dan online, penyusunan harga berdasarkan bundle pricing policy, kerja sama dengan komponenkomponen pariwisata, kondisi keuangan perusahaan cukup baik, penyebaran kuesioner sebagai bahan evaluasi, penggunaan data base sebagai pusat informasi.

\section{Identifikasti SWOT terhadap faktor kelemahan}

Faktor-faktor yang menjadi kelemahan perusahaan, adalah: tidak ada pencatatan tahapan kerja secara eksplisit, permasalahan skala prioritas, rapat evaluasi tidak rutin, tidak ada divisi pemasaran, ketergantungan dengan agen luar negeri, tata letak ruang kerja tidak ideal dengan jumlah karyawan, pakaian seragam tidak digunakan oleh karyawan, promosi tidak maksimal, beberapa karyawan lebih menyukai bekerja dengan sistem offline, pemanfaatan teknologi yang dimiliki perusahaan tidak maksimal.

\subsection{Analisis Lingkungan Eksternal Perusahaan}

Lingkungan eksternal perusahaan berdasarkan teori Industrial Organization (IO) dianggap lebih besar dibandingkan keputusan internal perusahaan terkait pencapaian keunggulan kompetitif. Hasil analisis terhadap lingkungan eksternal yang mencakup faktor peluang dan ancaman perusahaan diidentifikasi menggunakan SWOT.

\section{Identifikasti SWOT terhadap faktor peluang}

Faktor-faktor yang menjadi peluang perusahaan, adalah: depresiasi Rupiah meningkatkan kunjungan wisatawan mancanegara, PDB dan PDRB Bali meningkat, diversifikasi produk, SDM pariwisata, kualitas infrastruktur, kondisi keamanan Bali, Garuda Indonesia terbang lagi ke Eropa, kebijakan visa, pembentukan outbound, kualitas pelayanan jasa.

\section{Identifikasti SWOT terhadap faktor ancaman}

Faktor-faktor yang menjadi ancaman perusahaan adalah: depresiasi Rupiah meningkatkan daya saing produk dan jasa, regulasi SUJPW, regulasi otda, perubahan harga BBM, kemajuan internet, intensitas persaingan semakin ketat, kombinasi paket wisata relatif sama, ketergantungan pada BPW luar negeri sebagai pemasok wisatawan, agen luar negeri mudah pindah ke BPW lain, switching cost rendah, wisatawan mudah pindah ke perusahaan lain. 


\subsection{Perumusan Strategi Bersaing}

Proses perumusan strategi bersaing dilakukan berdasarkan teori bersaing melalui tiga tahap, yaitu: strategi umum, alternatif dan prioritas.

\subsubsection{Analisis Strategi Umum}

Analisis strategi umum dilakukan dengan alat bantu matriks IFE dan EFE. Hasil pengolahan matriks IFE secara rinci disajikan pada Tabel 3.1. Total nilai IFE adalah 2,9403 yang mengindikasikan posisi internal perusahaan yang kuat. Total nilai IFE kekuatan adalah 1,7470 dan kelemahan 1,1933 yang mengindikasikan bahwa faktor kekuatan lebih besar daripada kelemahan. Perhitungan matriks IFE menunjukkan faktor bundle pricing policy sebagai kekuatan utama Alindo Tours dengan nilai tertimbang tertinggi yaitu sebesar o,1953. Faktor SIM menjadi kelemahan utama Alindo Tours dengan nilai tertimbang 0,0424.

Hasil pengolahan matriks EFE secara rinici disajikan pada Tabel 3.2. Total nilai EFE adalah 2,4408 yang mengindikasikan bahwa perusahaan berada di bawah rata-rata dalam melakukan upaya strategi bersaing. Total nilai faktor eksternal peluang adalah 1,1792 dan ancaman 1,2617 yang menunjukkan faktor ancaman lebih besar daripada peluang. Perhitungan matriks IFE menunjukkan faktor kualitas layanan jasa merupakan peluang utama bagi Alindo Tours dengan nilai tertimbang terbesar yaitu o,1784. Ketergantungan dengan agen luar merupakan ancaman utama dengan nilai tertimbang 0,1964.

Tabel 1 Analisis Matriks IFE Perusahaan Alindo

\begin{tabular}{cccc}
\hline \multicolumn{1}{c}{ Faktor Strategis Internal } & Bobot & Rating & Skor \\
\hline Kekuatan & & & \\
A Pembagian kerja jelas & 0,0550 & 3,5 & 0,1925 \\
B Rekrutmen sesuai kemampuan & 0,0550 & 3,5 & 0,1925 \\
C Dua orang eksptriat Perancis & 0,0483 & 3,5 & 0,1691 \\
D Paket wisata bervariasi & 0,0513 & 3,5 & 0,1796 \\
E Pemasaran offline \& online & 0,0446 & 3,5 & 0,1561 \\
F Bundle pricing policy & 0,0558 & 3,5 & 0,1953 \\
G Kerjasama dg komponen par. & 0,0506 & 3,5 & 0,1771 \\
H Kondisi keuangan cukup baik & 0,0498 & 3,5 & 0,1743 \\
I Penyebaran kuesioner & 0,0521 & 3,5 & 0,1824 \\
J Penggunaan data base & 0,0513 & 2,5 & 0,1283 \\
Total & & & 1,7470 \\
\hline Kelemahan & & & \\
K Pencatatan eksplisit & 0,0498 & 3 & 0,1494 \\
L Skala prioritas & 0,0491 & 3 & 0,1473 \\
M Rapat evaluasi tidak rutin & 0,0520 & 2,5 & 0,1300 \\
N Responsible untuk pemasaran & 0,0498 & 3,5 & 0,1743
\end{tabular}




\begin{tabular}{llccc} 
O & Ketergantungan agen luar & 0,0446 & 3 & 0,1338 \\
P & Tata letak ruang kerja & 0,0506 & 1 & 0,0506 \\
Q & Pakaian seragam tidak dipakai & 0,0513 & 2,5 & 0,1283 \\
R & Promosi tidak maksimal & 0,0461 & 3,5 & 0,1614 \\
S & Karyawan memilih sistem offline & 0,0506 & 1,5 & 0,0759 \\
T & SIM tidak maksimal & 0,0424 & 1 & 0,0424 \\
\hline \multicolumn{2}{c}{ Total } & & & 1,1933 \\
\hline \multicolumn{2}{c}{ Total IFE } & & 2,9403 \\
\hline
\end{tabular}

Tabel 2 Analisis Matriks EFE Perusahaan Alindo

\begin{tabular}{|c|c|c|c|c|}
\hline & Faktor Strategis Eksternal & Bobot & Rating & Skor \\
\hline \multicolumn{5}{|c|}{ Peluang } \\
\hline A & Dep.Rp. Wisatawan meningkat & 0,0562 & 1,5 & 0,0843 \\
\hline $\mathrm{B}$ & Wisata/Ibadah utk masyarakat & 0,0452 & 2 & 0,0904 \\
\hline $\mathrm{C}$ & Diversifikasi produk & 0,0413 & 4 & 0,1652 \\
\hline $\mathrm{D}$ & Ketersediaan SDM pariwisata & 0,0504 & 2,5 & 0,1260 \\
\hline $\mathrm{E}$ & Kualitas infrastruktur & 0,0640 & 1,5 & 0,0960 \\
\hline $\mathrm{F}$ & Kondisi keamanan Bali & 0,0588 & 1 & 0,0588 \\
\hline G & Garuda kembali terbang ke Eropa & 0,0607 & 2,5 & 0,1518 \\
\hline $\mathrm{H}$ & Kebijakan visa & 0,0510 & 2,5 & 0,1275 \\
\hline I & Pembentukan outbound & 0,0504 & 2 & 0,1008 \\
\hline $\mathrm{J}$ & Kualitas pemberian layanan jasa & 0,0446 & 4 & 0,1784 \\
\hline Tota & & & & 1,1792 \\
\hline \multicolumn{5}{|c|}{ Ancaman } \\
\hline $\mathrm{K}$ & Dep.Rp. Daya saing meningkat & 0,0523 & 2,5 & 0,1308 \\
\hline $\mathrm{L}$ & Regulasi SUJPW & 0,0497 & 1 & 0,0497 \\
\hline M & Kenaikan tiket obyek wisata & 0,0420 & 2 & 0,0840 \\
\hline $\mathrm{N}$ & Perubahan harga BBM & 0,0530 & 2,5 & 0,1325 \\
\hline $\mathrm{O}$ & Informasi pariwisata via internet & 0,0485 & 4 & 0,1940 \\
\hline $\mathrm{P}$ & Persaingan BPW & 0,0446 & 3 & 0,1338 \\
\hline $\mathrm{Q}$ & Kombinasi paket wisata sama & 0,0413 & 3,5 & 0,1446 \\
\hline $\mathrm{R}$ & Ketergantungan dg agen luar & 0,0491 & 4 & 0,1964 \\
\hline $\mathrm{S}$ & Agen luar mudah pindah & 0,0478 & 1,5 & 0,0717 \\
\hline $\mathrm{T}$ & Switching cost rendah & 0,0497 & 2,5 & 0,1243 \\
\hline \multicolumn{3}{|c|}{ Total } & \multicolumn{2}{|r|}{1,2617} \\
\hline \multicolumn{3}{|c|}{ Total EFE } & & 2,4408 \\
\hline
\end{tabular}

\subsubsection{Analisis Strategi Alternatif}

Bagian ini menyajikan beberapa alternatif strategi yang dapat dirumuskan berdasarkan data dari strategi umum. Perumusan strategi alternatif menggunakan matriks IE dan SWOT. Analisis Matriks Internal External 
Berdasarkan hasil pengolahan matriks IFE dan EFE dapat disimpulkan bahwa: total nilai tertimbang IFE Alindo Tours adalah sebesar 2,9403 dan total nilai tertimbang EFE Alindo Tours adalah sebesar 2,4408. Total nilai tertimbang dari faktor internal dan eksternal menempatkan posisi perusahaan pada sel ke lima (V) yang secara rinci disajikan pada Gambar 1 Penempatan sel ke lima (V) mengidentifikasi, bahwa perusahaan mempunyai posisi bersaing yang lemah. Strategi yang tepat dalam kondisi ini adalah penetrasi pasar dan pengembangan produk.

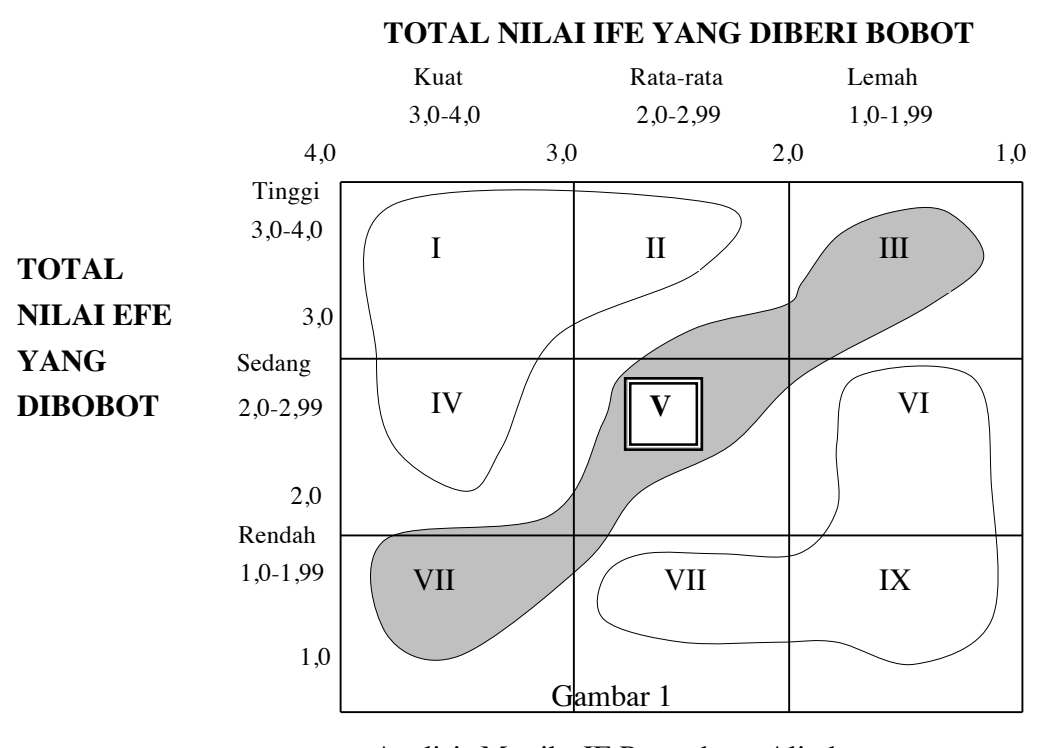

Analisis Matriks IE Perusahaan Alindo

Gambar 1 Analisis Matriks IE Perusahaan Alindo

Analisis Matriks SWOT

Analisis matriks SWOT menghasilkan delapan strategi yang dikembangkan dalam empat tipe strategi bersaing, yang mencakup: strategi Strengths-Opportunities (S-O), strategi Weaknesses-Opportunities (W-O), strategi Strengths-Threats (S-T) dan strategi Weaknesses-Threats (W-T)

a. Strategi Strengths-Opportunities (S-O)

Alternatif strategi S-O perusahaan Alindo Tours yaitu mengembangkan segmen pasar dan membuat paket wisata yang diminati wisatawan mancanegara dan domestik.

b. Strategi Weaknesses-Opportunities (W-O)

Alternatif strategi W-O perusahaan Alindo Tours, yaitu membentuk divisi pemasaran, meningkatkan penjualan dan kualitas layanan, produk melalui teknologi. 


\section{c. Strategi Strengths-Threats (S-T)}

Alternatif strategi S-T perusahaan Alindo Tours adalah memberikan harga yang kompetitif dengan tetap menjaga kualitas produk, dan mengupayakan promosi di dalam maupun luar negeri.

\section{d. Strategi Weaknesses-Threats (W-T)}

Alternatif strategi W-T perusahaan Alindo Tours adalah meningkatkan kualitas SDM melalui pelatihan dan membuat sistem yang bisa mengintegrasikan seluruh divisi.

Berbagai kekuatan dan kelemahan internal yang dimiliki perusahaan disesuaikan dengan peluang dan ancaman eksternal perusahaan. Secara rinci analisis matriks SWOT disajikan pada Gambar 2.

\begin{tabular}{|c|c|c|}
\hline & S: Strengths & W: Weaknesses \\
\hline \multirow[t]{8}{*}{ Faktor Internal } & 1. Pembagian kerja jelas & 1. Pencatatan eksplisit \\
\hline & $\begin{array}{l}\text { 2. Rekrutm sesuai kemam- } \\
\text { puan }\end{array}$ & 2. Skala prioritas \\
\hline & 3. Dua ekspatriat Perancis & 3. Rapat evaluasi tdk rutin \\
\hline & 4. Paket wisata bervariasi & 4. Responsible pemasaran \\
\hline & 5. Pemasaran offline-online & $\begin{array}{l}\text { 5. Ketergantungan agen } \\
\text { luar }\end{array}$ \\
\hline & 6. Bundle pricing policy & 6. Tata letak ruang kerja \\
\hline & $\begin{array}{l}\text { 7. Kerjasama dg komponen } \\
\text { par }\end{array}$ & 7. Seragam tdk dipakai \\
\hline & 8. Kondisi keuangan baik & 8. Promosi tidak maksimal \\
\hline \multirow[t]{2}{*}{ Faktor Eksternal } & 9. Penyebaran kuesioner & 9. Karyw kerja offline \\
\hline & 10. Penggunaan data base & 10. SIM tidak maksimal \\
\hline O: Opportunities & Strategi S-O & Strategi W-O \\
\hline
\end{tabular}

1. Dep.Rp. wisatwn mening-1. Mengembangkan segmen 1. Membentuk divisi pekat

2. Wisata/ibadah utk pasar, baik mancanegaradan domestik. masaran, guna meningmasykt. katkan penjualan.

3. Diversifikasi produk
4. SDM pariwisata
$\mathrm{S} 1, \mathrm{~S}_{2}, \mathrm{~S} 4, \mathrm{~S} 5, \mathrm{~S} 6, \mathrm{~S} 7, \mathrm{~S} 8, \mathrm{O} 1 \quad \mathrm{~W} 1, \mathrm{~W}_{2} \mathrm{~W}_{4}, \mathrm{~W}_{5}, \mathrm{~W}_{7}$,
5. Kualitas infrasutruktur
$\mathrm{O}_{2}, \mathrm{O}_{3}, \mathrm{O}_{4}, \mathrm{O} 6, \mathrm{O}_{7}, \mathrm{O} 8, \mathrm{O} 9 \mathrm{~W} 8, \mathrm{~W} 10, \mathrm{O}_{4}$.
6. Kondisi keamanan Bali
2. Membuat paket wisata
2. Meningkatkan kualitas
7. Garuda terbang ke Eropa
yang diminati wisatawan
layanan, produk melalui
8. Kebijakan visa
Nusantara \& mancanegara. teknologi.
9. Pembentukan outbound
$\mathrm{S}_{3}, \mathrm{~S}_{4}, \mathrm{~S} 5, \mathrm{~S} 6, \mathrm{~S}_{7}, \mathrm{O}_{1}, \mathrm{O}_{2}, \mathrm{~W}_{3}, \mathrm{~W} 6, \mathrm{~W}_{7}, \mathrm{~W}_{9}, \mathrm{~W}_{10}$,
10. Kualitas layanan jasa
$\mathrm{O}_{3}, \mathrm{O}_{5}, \mathrm{O} 6, \mathrm{O}_{7}, \mathrm{O} 8, \mathrm{O} 9$.
$\mathrm{O}_{4}, \mathrm{O}_{5}, \mathrm{O}_{10}$.

T: Threats

Strategi S-T

1. Dep.Rp. daya saing naik

1. Memberikan harga yang 1 . Meningkatkan kualitas

2. Regulasi SUJPW kompetitif dengan tetap SDM melalui pelatihan.

3. Kenaikan tiket obyek wisata

4. Perubahan harga BBM menjaga kualitas produk. W3, W6, W9, T1, T6.

S6, S9, S10, $\mathrm{T} 1, \mathrm{~T}_{2}, \mathrm{~T}_{3}, \mathrm{~T} 4, \mathrm{~T} 6, \mathrm{~T} 7$,

5. Informasi par. via interT10. net 
6. Persaingan BPW

7. Kombinasi paket wisata

8. Ketergantungan agen luar

9. Agen luar mudah pindah $\mathrm{T}_{5}, \mathrm{~T} 8, \mathrm{~T} 9, \mathrm{~T} 10$

10. Switching cost rendah $\begin{array}{lll}\text { 2. Mengupayakan promosi } & \text { 2. Membuat sistem yang }\end{array}$

di dalam dan luar negeri. meintegrasikan seluruh S4, S5, S6, S7, S8, S10, T1, divisi.

Gambar 2 Analisis Matriks SWOT

\subsubsection{Keputusan Strategi Prioritas}

Keputusan strategi prioritas dilakukan dengan alat analisis QSPM, secara berurutan atau bersamaan dengan memadukan faktor-faktor internal dan eksternal yang terkait dalam proses keputusan. Penentuan strategi melalui QSPM memerlukan keputusan subyektif untuk menunjukkan perhatian akan pentingnya hubungan-hubungan yang mempengaruhi keputusankeputusan.

Hasil analisis QSPM Alindo Tours pada Tabel 3 menunjukkan strategi prioritas. Adapun strategi yang memiliki daya tarik tertinggi sebesar 5,4419 adalah mengembangkan segmen pasar, baik mancanegara dan domestik.

Tabel 3 Analisis Quantitative Strategic Planning Matriks Perusahaan Alindo

\begin{tabular}{lccrcc}
\hline \multirow{2}{*}{ Strategi } & \multicolumn{2}{c}{ Strategi TAS } & \multirow{2}{*}{ Jumlah } & Rata-Rata & \multirow{2}{*}{ Peringkat } \\
\cline { 2 - 4 } & Informan 1 & Informan 2 & & & \\
\hline SO1 & 56,394 & 52,443 & 108,837 & 54,419 & 1 \\
SO2 & 50,484 & 45,486 & 95,970 & 47,985 & 5 \\
WO1 & 43,818 & 44,773 & 88,591 & 44,296 & 8 \\
WO2 & 46,836 & 42,055 & 88,891 & 44,446 & 7 \\
ST1 & 53,812 & 50,370 & 104,182 & 52,091 & 3 \\
ST2 & 45,997 & 47,858 & 93,855 & 46,928 & 6 \\
WT1 & 52,281 & 48,013 & 100,294 & 50,147 & 4 \\
WT2 & 56,001 & 50,862 & 106,863 & 53,432 & 2 \\
\hline
\end{tabular}

\section{Simpulan dan Saran}

Faktor internal kekuatan perusahaan mencakup: pembagian kerja berdasarkan struktur organisasi, rekrutmen karyawan baru sesuai kemampuan, keberadaan dua orang ekspatriat Perancis, pembuatan paket wisata bervariasi, pemasaran dilakukan secara offline dan online, penetapan harga melalui bundle pricing policy, kerjasama yang baik dengan komponen-komponen pariwisata, kondisi keuangan perusaahaan cukup baik, penyebaran kuesioner kepada wisatawan yang ditangani perusahaan, penggunaan data base. Faktor internal kelemahan perusahaan, adalah: pencatatan tahapan kerja tidak dilakukan secara eksplisit, pelaksanaan kegiatan operasional tidak sesuai dengan skala prioritas, rapat evaluasi tidak dilakukan secara 
rutin, penanggung jawab terhadap keseluruhan kegiatan pemasaran tidak ada, ketergantungan kerjasama dengan agen di luar negeri, tata letak ruang kerja tidak rapih, pakaian seragam sebagai identitas perusahaan tidak dipakai oleh karyawan, promosi melalui media sosial tidak maksimal, karyawan memilih kerja offline, dibandingkan secara online, pelaksanaan SIM tidak maksimal.

Faktor eksternal peluang perusahaan mencakup: depresiasi Rupiah meningkatkan wisatawan khususnya mancanegara, keinginan masyarakat melakukan wisata atau beribadah, diversifikasi produk wisata mudah dilakukan, ketersediaan SDM pariwisata melalui lembaga pendidikan, kualitas infrastruktur yang baik dengan berbagai pilihan, kondisi keamanan Bali, Garuda Indonesia terbang lagi ke Eropa, kebijakan visa bagi negara-negara penerima, pembentukan divisi outbound, kualitas pemberian jasa. Faktor eksternal ancaman perusahaan, yaitu: depresiasi Rupiah meningkatkan daya saing pemberian jasa, regulasi SUJPW bagi biro perjalanan wisata, kenaikan tiket obyek wisata tanpa disosialisasikan, perubahan harga BBM yang sering terjadi, informasi pariwisata mudah diperoleh melalui internet, persaingan antar BPW, kombinasi paket wisata antar BPW sama, posisi agen luar negeri mendominasi, agen luar negeri mudah pindah ke BPW lain, switching cost perusahaan rendah yang mengakibatkan wisatawan pindah ke perusahaan lain.

Strategi bersaing yang harus diterapkan pada Biro Perjalanan Wisata Alindo Dewata Tours, mencakup delapan strategi dengan skala prioritas, sebagai berikut:

1. Mengembangkan segmen pasar, baik mancanegara dan domestik.

2. Membuat sistem yang mengintegrasikan seluruh divisi.

3. Memberikan harga yang kompetitif dengan tetap menjaga kualitas produk.

4. Meningkatkan kualitas SDM melalui pelatihan.

5. Membuat paket wisata yang diminati wisatawan nusantara dan mancanegara.

6. Mengupayakan promosi di dalam dan luar negeri.

7. Meningkatkan kualitas produk wisata melalui teknologi.

8. Membentuk divisi pemasaran, guna meningkatkan penjualan.

Biro Perjalanan Wisata Alindo Dewata Tours disarankan lebih giat menggali pasar Perancis, dengan mengoptimalkan kinerja dua ekspatriat Perancis dan lima karyawan berbahasa Perancis. Pasar Perancis yang digali tidak hanya wisatawan dari Negara Perancis tetapi juga negara-negara yang berbahasa Perancis, seperti Belgia, Kanada, dan Switzerland. Wisatawan Perancis menyukai kebudayaan tradisional suatu negara, namun tetap menyukai komunikasi dengan bahasa Perancis. Oleh karenanya, ekspatriat maupun karyawan berbahasa Perancis sebaiknya menciptakan program atau paket wisata yang unik dalam bahasa Perancis. Contoh, paket wisata 
menginap di rumah penduduk dan ikut dalam kegiatan mencocok tanam. Paket wisata unik bisa menjadi keunggulan kompetitif bagi perusahaan Alindo, karena tidak dimiliki pesaing. Perusahaan harus terus menerus menciptakan paket-paket wisata unik, sehingga menjadi keunggulan kompetitif yang berkelanjutan.

Lingkungan industri sebagai salah satu aspek penting dalam penentuan strategi bersaing pada biro perjalanan wisata belum diulas secara mendalam pada penelitian ini. Ulasan lingkungan industri secara mendalam pada penelitian ini hanya terkait pada pesaing utama perusahaan, sedangkan pesaing-pesaing lain diulas secara garis besar saja. Oleh karenanya, kepada peneliti selanjutnya disarankan untuk dapat meneliti lebih dalam mengenai pesaing-pesaing yang dihadapi suatu biro perjalanan wisata.

\section{Ucapan Terima Kasih}

Penulis menyampaikan ucapan terimakasih kepada Prof. Dr. Ni Wayan Sri Suprapti, SE, MSi dan Dr. I Nyoman Madiun M.Sc selaku pembimbing utama dan pendamping yang telah dengan penuh pengertian memberikan bimbingan selama penulisan tesis. Prof. Dr. I Nyoman Darma Putra, M.Litt selaku Ketua Program Studi Pascasarjana Kajian Pariwisata Universitas Udayana sekaligus penguji, Prof. Dr. Made Budiarsa, M.A. dan Prof. Dr. Ir. Made Antara, MS. selaku penguji, atas masukan untuk penyempurnaan tesis. Seluruh dosen pengajar dan staf administrasi pada Program Studi Magister Kajian Pariwisata. Bapak Putu Djirna selaku Advisor, Bapak Nyoman Trijata selaku Managing Director, Ibu Eny Istianingsih selaku Manager Production dan Ibu Rai Puspasari Astuti selaku Accounting Manager Alindo Dewata Tours, atas seluruh informasi dan keterlibatannya dalam menganalisis strategi bersaing perusahaan.

\section{Daftar Pustaka}

Barney, Jay B. 2001. "Resource-Based Theories Of Competitive Advantage: A Ten Year Retrospective On The Resource-Based View” (Journal of Management), 27, 643-650.USA: Elsevier Science.

Church, Jeffrey, Roger Ware. 200o. Industrial Organization, A Strategic Approach. USA: McGraw Hill.

David, Fred R. 2004. Manajemen Strategis, Konsep-Konsep. (Kreso Saroso, Pentj). Jakarta: Indeks Kelompok Gramedia.

Foster, Dennis L. 2000. First Class An Introduction To Travel \& Tourism. Second Edition. Edisi Bahasa Indonesia. (Tri Budhi Sastrio, Pentj). Jakarta: RajaGrafindo Persada.

Kotler, Philip. 2005. Manajemen Pemasaran, Jilid I. Diterjemahkan oleh Molan. Jakarta: PT. Indeks Kelompok Gramedia.

Langabeerll, James R, John Napiewocki. 2000. Competitive Business Strategy For 
Teaching Hospitals. USA: Greenwood Publishing Group. Inc.

Mahoney, Joseph T, J. Rajendran Pandian. 1992. “The Resource-Based View Within

The Conversation Of Strategic Management" (Strategic Management Journal),

Vol. 13 No. 5, 363-380. USA: John Wiley \& Sons.

Payne, Adrian. 2009. The Essence of Serivce Marketing Pemasaran Jasa. (Fandy

Tjiptono, Pentj). Yogyakarta: Andi.

Picard, Michel. 2006. Bali Pariwisata Budaya dan Budaya Pariwisata. Jakarta:

Kepustakaan Populer Gramedia.

Shinta, Agustina. 2011. Manajemen Pemasaran. Malang: Universitas Brawijaya Press (UB Press).

Suprapti, Ni Wayan Sri. 2010. Perilaku Konsumen, Pemahaman Dasar dan Aplikasinya dalam Strategi Pemasaran. Bali: Udayana Universy Press.

Sugiyono. 2010. Metode Penelitian Kuantitatif, Kualitatif, Dan R\&D. Bandung: Alfabeta.

Swastha, Basu dan Irawan. 2008. Manajemen Pemasaran Modern. Yogyakarta: Liberty.

Thompson, Arthur A, Jr, A.J. Strickland III, John E. Gamble. 2008. Crafting and Executing Strategy, The Quest for Competitive Advantage, Concepts and Cases, $16^{\text {th }}$ Edition. USA: McGraw-Hill International Edition.

Tsiotsou, Rodoula dan Vanessa Ratten. 2010. "Future Research Directions in Planning” (Jurnal Tourism Marketing). Marketing Intelligence \& Planning. Vol. 28 No. 4, 2010, pp.533-544. Emerald Group Publishing Limited.

Vellas, Francois, Lionel Becherel. 2008. Pariwisata Internasional, Sebuah Pendekatan Strategis. Jakarta: Yayasan Obor Indonesia.

Wardiyanta, 2006. Metode Penelitian Pariwisata. Yogyakarta: Andi.

Wirartha, I Made. 2006. Metodologi Penelitian Sosial Ekonomi. Yogyakarta: Andi. Yoeti, Oka A. 2006. Tours and Travel Marketing. Jakarta: Pradnya Paramita.

\section{Profil Penulis}

Nelsye Natalina Lintong, SE, M.Par adalah seorang praktisi pariwisata yang bekerja di sebuah biro perjalanan wisata. Penulis menyelesaikan Program Magister Pariwisata di Universitas Udayana tahun 2015. Program sarjana diselesaikan tahun 2011 di Fakultas Ekonomi Universitas Ngurah Rai Bali sebagai mahasiswa terbaik. Penulis pernah menempuh pendidikan di Fakultas Sosial dan Politik Universitas Sam Ratulangi Manado melalui jalur Penelusuran Minat dan Kemampuan (PMDK), pada tahun 1987-1988. Peluang pekerjaan di bidang pariwisata yang lebih menjanjikan merupakan alasan penulis masuk School of Tourism Manado pada tahun 1988-1989 dan menyelesaikan pendidikan dengan prestasi the best student. 